\title{
Predicting the variation in Echinogammarus marinus at its southernmost limits under global warming scenarios: Can the sex-ratio make a difference?
}

\author{
Alexandra Guerra ${ }^{\mathrm{a}, *}$, Nuno Leite ${ }^{\mathrm{a}}$, João Carlos Marques ${ }^{\mathrm{a}}$, Alex T. Ford ${ }^{\mathrm{b}}$, Irene Martins ${ }^{\mathrm{a}}$ \\ a IMAR - Institute of Marine Research, Marine and Environmental Research Centre, Department of Life Sciences, Faculty of Sciences and Technology, University of Coimbra, \\ 3004-517 Coimbra, Portugal \\ b School of Biological Sciences, University of Portsmouth, King Henry Building, Portsmouth PO1 2DT, England, UK
}

\section{H I G H L I G H T S}

- Echinogammarus marinus is highly sensitive to temperature rises.

- Expected temperature increases will cause a withdrawal of $5^{\circ} \mathrm{N}$ of $E$. marinus populations.

- Female-biased populations are more resistant to temperature rises than male-biased.

- Sex-ratio adjustment can be a counteracting mechanism of climatic adverse effects.

\section{A R T I C L E I N F O}

\section{Article history:}

Received 25 January 2013

Received in revised form 28 July 2013

Accepted 28 July 2013

Available online 30 August 2013

Editor: Mark Hanson

\section{Keywords:}

Amphipods

Extreme limit

Climate change

Sex-ratio

Female-biased

Resilience

\begin{abstract}
A B S T R A C T
Understanding the environmental parameters that constrain the distribution of a species at its latitudinal extremes is critical for predicting how ecosystems react to climate change. Our first aim was to predict the variation in the amphipod populations of Echinogammarus marinus from the southernmost limit of its distribution under global warming scenarios. Our second aim was to test whether sex-ratio fluctuations - a mechanism frequently displayed by amphipods - respond to the variations in populations under altered climate conditions. To achieve these aims, scenarios were run with a validated model of E. marinus populations. Simulations were divided into: phase I - simulation of the effect of climate change on amphipod populations, and phase II - simulation of the effect of climate change on populations with male and female proportions. In both phases, temperature (T), salinity $(\mathrm{S})$ and temperature and salinity (T-S) were tested.

Results showed that $E$. marinus populations are highly sensitive to increases in temperature $\left(>2{ }^{\circ} \mathrm{C}\right)$, which has adverse effects on amphipod recruitment and growth. Results from the climate change scenarios coupled with the sex-ratio fluctuations depended largely on the degree of female bias within population. Temperature increase of $2{ }^{\circ} \mathrm{C}$ had less impact on female-biased populations, particularly when conjugated with increases in salinity. Male-biased populations were highly sensitive to any variation in temperature and/or salinity; these populations exhibited a long-term decline in density. Simulations in which temperature increased more than $4{ }^{\circ} \mathrm{C}$ led to a continuous decline in the E. marinus population. According to this work, E. marinus populations at their southernmost limit are vulnerable to global warming. We anticipate that in Europe, temperature increases of $2{ }^{\circ} \mathrm{C}$ will incite a withdrawal of the population of $5^{\circ} \mathrm{N}$ from the amphipod species located at southernmost geographical borders. This effect is discussed in relation to the distribution of $E$. marinus along the Atlantic coast.
\end{abstract}

(C) 2013 Elsevier B.V. All rights reserved.

\section{Introduction}

Climate change and the associated rise in sea level have the potential to cause changes in estuarine physical properties in a number of ways,

\footnotetext{
* Corresponding author at: IMAR - Institute of Marine Research, Marine and Environmental Research Centre, Department of Life Sciences, University of Coimbra, 3004-517 Coimbra, Portugal. Tel.: + 351239836 386; fax: + 351239823603.

E-mail address: mariamartins.g@gmail.com (A. Guerra).
}

thereby influencing the ecology of estuarine-dependent organisms (Fujii, 2012). In addition to global warming and ad rise in sea level, there are predicted changes in terms of the frequency of severe droughts, excessive precipitation and extreme events (Sagarin et al., 1999; Denny and Wethey, 2001; Jentsch and Beierkuhnlein, 2008). These phenomena will lead to serious disturbances to the estuarine ecosystem, characterized by variations in temperature and salinity (Cayan and Peterson, 1993; Justić et al., 1996; Fujii, 2012; Jentsch and Beierkuhnlein, 2008). For estuarine amphipods in the tidal zone, which experience major 


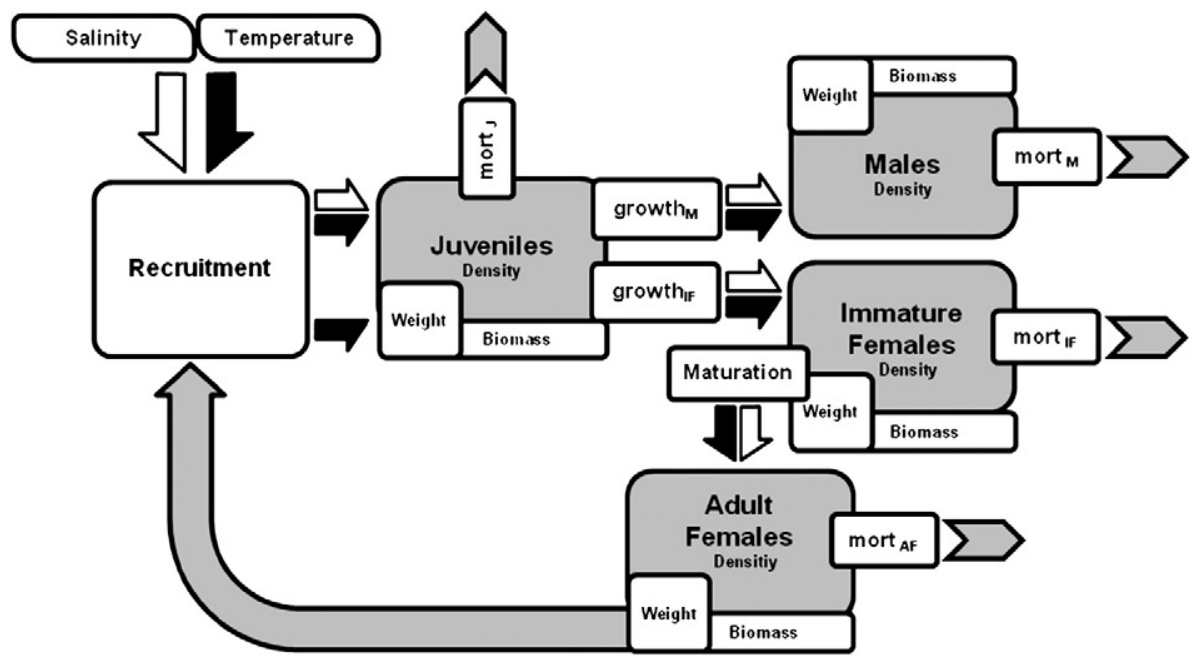

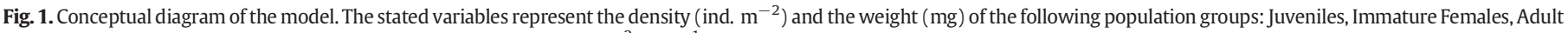

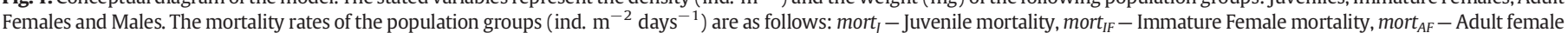

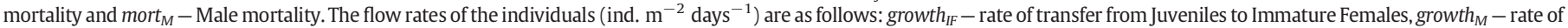
transfer from Juveniles to Males, Maturation and Recruitment (ind. $\mathrm{m}^{-2}$ days ${ }^{-1}$ ). Addition variables were Temperature $\left({ }^{\circ} \mathrm{C}\right)$ and Salinity (psu). See Martins et al., 2002 for details.

short-term, long-term or seasonal variations in the environmental temperature and the seawater osmolality (Maranhão and Marques, 2003), variations in these two abiotic variables (temperature and salinity) may modify the structure, function, and distribution of these estuarine organisms (McKenney, 1996). Temperature affects these organisms through the control of metabolic rates and the linked effects it can have on reproductive efforts. Salinity effects molting and reproductive success (Cunha et al., 2000; Maranhão and Marques, 2003).

When the climate or other conditions shift, organisms initially respond with physiological and behavioral adaptations (Somero, 2012). If adaptation to the new conditions is not possible, the individuals or populations may migrate or become locally extinct (Parmesan, 2006). The majority of the literature on the impact of climate change, particularly in Europe, focuses on shifts in the geographical ranges of species (Southward et al., 1995; Herbert et al., 2003; Helmuth et al., 2006; Mieszkowska et al., 2007; Wethey and Woodin, 2008; Hawkins et al., 2009). This evidence suggests that in response to warmer conditions, invertebrates tend to shift their distributions to higher latitudes according to their thermal tolerance and ability to adapt (Harley et al., 2006; Parmesan, 2006; Helmuth et al., 2006; Hawkins et al., 2009; Mueter and Litzow, 2008; Lucey and Nye, 2010). Other studies conducted on population- and community-level processes suggest that the climatic impacts on individual organisms do not necessarily translate directly into changes in distribution (Harley et al., 2006). Many observations concerning the climate change response have involved the alterations of the phonologies of species (Parmesan, 2006). Species that are adapted to large environmental fluctuations usually have a short life span, mature early, produce many offspring and suffer from high fluctuations in population levels. These are typical characteristics and strategies at early successional stages (Pianka, 1970). Studies on marine invertebrates reported changes in population dynamics and reproductive biology to address stressful conditions caused by climate variations. These specific strategies involve shifts in the following factors: lifespan (Berezina and Gubelit, 2012); life cycles (Donn and Croker, 1986; Wildish, 1984; SainteMarie, 1991; Beaugrand et al., 2002); reproductive patterns (Van Dolah and Bird, 1980; Kolding and Fenchel, 1981; Skadsheim, 1984; Pardal et al., 2000), and sex-ratio (the proportion of males to

Table 1

Main equations of the model.

\begin{tabular}{|c|c|}
\hline $\begin{array}{l}\frac{\partial J}{\partial t}=\text { recruitment }^{- \text {mort }_{J}}-\text { growth }_{I F}-\text { growt }_{M} \\
\frac{\partial I F}{\partial t}=\text { growth }_{I F}-\text { mort }_{I F}-\text { maturation } \\
\frac{\partial M}{\partial t}=\text { growth }_{M}-\text { mort }_{M} \\
\frac{\partial A F}{\partial t}=\text { maturation } \text { mort }_{A F} \\
\text { mort }_{J, I F, A F, M}=\text { mort }_{J, I F, A F, M} \times \text { Density }_{J, I F, A F, M} \\
\text { Recruitment }=N B J \times f(S) \times f(T) \times 0.0291 \times A F \\
A v W=\frac{W_{i-1}+W_{i}}{2}\end{array}$ & $\begin{array}{l}\text { Variation of juvenile density per unit of time } \\
\text { Variation of young female density per unit of time } \\
\text { Variation of male density per unit of time } \\
\text { Variation of adult female density per unit of time } \\
\text { Mortality rate of population groups as a function of density } \\
\text { Number of newly hatched juveniles (NBJ) from adult females per unit of time } \\
\text { Average weight of population groups }\end{array}$ \\
\hline $\begin{aligned} W_{i}=W_{i-1} & +f(T) \times \text { days }_{i-1, i} \\
& \times\left(h+W_{i-1}^{2 / 3}-k \times W_{i-1}\right)\end{aligned}$ & Weight of Echinogammarus marinus at the end of population group $i$ \\
\hline $\begin{array}{c}D W=1,592924 \times C L^{3,94344} \\
N B J=0 \text { for salinity } \leq 4 \\
N B J=-70.3+62.8 \times C L_{A F} \text { for temperature }<15 \\
N B J=-50.4+44.8 \times C L_{A F} \text { for temperature } \\
\quad \geq 15 \text { and }<23 \\
N B J=-11.7+12.2 \times C L_{A F} \text { for temperature } \geq 23\end{array}$ & $\begin{array}{l}\text { Regression between dry weight and cephalic length } \\
\text { Significant regression }(\mathrm{p}<0.05) \text { between the number of newly hatched juveniles } \\
\text { and females cephalic length and dependency of NBJ on salinity and temperature }\end{array}$ \\
\hline$f(T)=\left(\frac{T}{T_{\text {opt }}}\right)^{2.5} \times e^{\left(1-\left(\frac{T}{T_{\text {opt }}}\right)^{2.5}\right)}$ for $T<T_{\text {opt }}$ & Effect of temperature on recruitment \\
\hline $\begin{array}{c}f(T)=1-\left(\frac{T-T_{\text {opt }}}{T_{\max }-T_{\text {opt }}}\right)^{2} \text { for } T \geq T_{\text {opt }} \\
f(S)=0 \text { else } f(S)=1 \text { for salinity }=4 \text { or salinity }<4\end{array}$ & Effect of salinity on recruitment \\
\hline
\end{tabular}




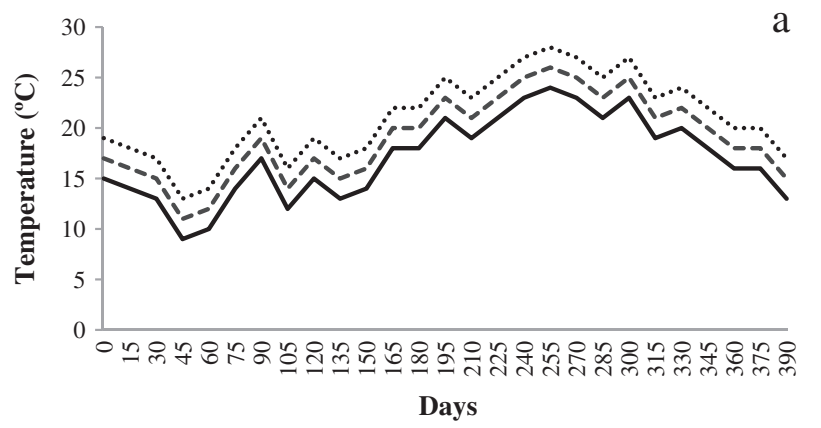

b

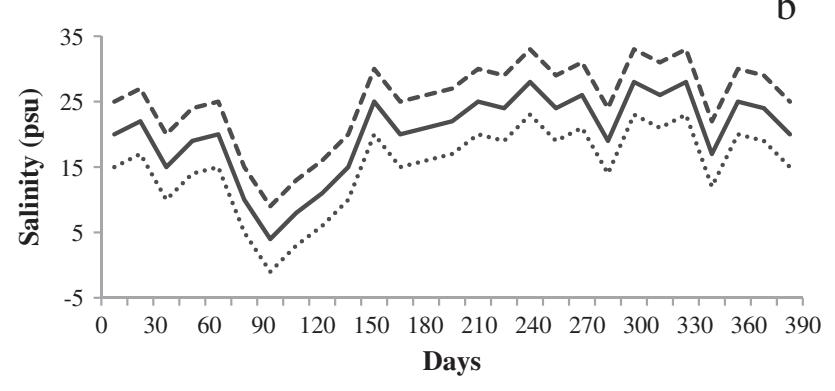

C

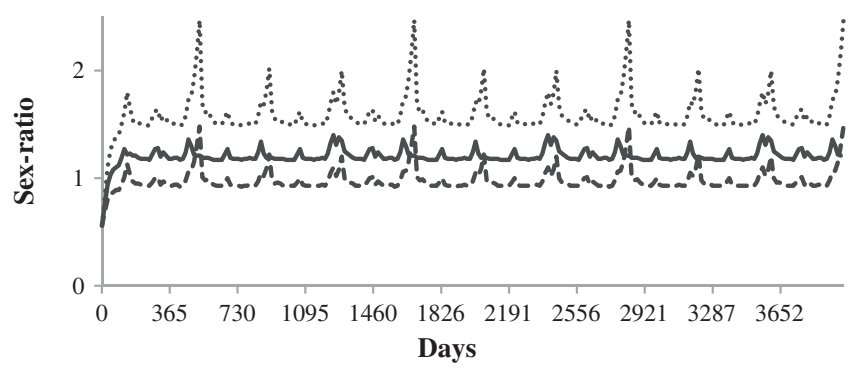

Fig. 2. Initial values of the Temperature (a), Salinity (b) and Sex-ratio (c) used in each scenario. (a) - The variation in temperature over time was used as follows: the base model (solid line) was achieved using data obtained by Maranhão et al. (2001); and the scenarios for temperature increases of $2{ }^{\circ} \mathrm{C}$ (dashed line) and $4{ }^{\circ} \mathrm{C}$ (dotted line) were obtained by the inflation/deflation of the initial values used in the base model $\left(+2{ }^{\circ} \mathrm{C}\right.$ and $+4{ }^{\circ} \mathrm{C}$, respectively). (b) - The variation in salinity variation over time was used as follows: the base model (solid line) was achieved using data obtained by Maranhão et al. (2001); and the scenarios for salinity increases of 5 psu (dashed line) and decreases of 5 psu (dotted line) were obtained by the inflation/deflation of the initial values used in the base model ( +5 psu and -5 psu, respectively). (c) - The fluctuations in the sex-ratio fluctuations over time were used as follows: in the base model (sex-ratio $=1$ ) (solid line); scenarios for female-biased (sex-ratio $<1$ ) (dashed line) and male-biased populations (sex-ratio > 1) (dotted line) were obtained by increasing (by 0.001) the initial growth and growth $h_{M}$ values, respectively, used in the base model.

females) (Vlasblom, 1969; Moore, 1981; Wildish, 1997; Lawrence and Soame, 2004). By exploring these effects of climate variation within a site, we can place this information in the context of larger scale variation (e.g., global climate change).

The Echinogammarus marinus Leach (E. marinus) is well-adapted to life in estuaries. This organism is a strongly euryhaline amphipod that can survive long emersion periods (Dorgelo, 1973; Pinkster and Broodbakker, 1980). The Mondego estuary is the southernmost distribution limit of this species, which extends from Norway to Portugal (Maren, 1975a, 1975b; Marques and Bellan-Santini, 1993). In the Mondego estuary, E. marinus is the most abundant species in intertidal communities on hard substrata (Marques et al., 1993). It feeds among the eulittoral Fucus vesiculosus (Phaeophyta) on rocky shores and is important prey for birds (Múrias et al., 1996, 1997). Previous studies on the biology, population dynamics, and productivity of E. marinus have shown that density, the percentage of ovigerous females, the sex-ratio, fecundity, and egg volume are affected by temperature and salinity (Marques and Nogueira, 1991; Maranhão et al., 2001). Temporal and geographical variations on their life cycle, reproductive patterns and sexual phenotypes have also been revealed (Marques and Nogueira, 1991; Maranhão et al., 2001; Ford et al., 2005, 2006; Martins et al., 2009).

The sex-ratio can either be 1:1 or skewed towards females or males (Moore, 1981). Amphipod populations often show seasonal fluctuations (Vlasblom, 1969) in the sex-ratio (the proportion of males to females); generally, females outnumber males (Powell and Moore, 1991; Cardoso and Veloso, 1996). Some of the factors behind these underlying differences in the sex-ratios of populations include the following: food availability, sex-based differences in lifespan longevity, reproductive strategies, and sexually biased predation and parasitic factors (Appadoo and Myers, 2004). These variations in the sex-ratio may also be regulated by environmental conditions. The sex of the offspring is determined by a key environmental trigger that signals to the developing embryo which sex will perform best under specific environmental conditions (Environmental Sex Determination - ESD, Charnov and Bull, 1977). A facultative decision can also be made by the mother based upon her perception of which sex will have the greater fitness returns given the current environment (Trivers and Willard, 1973). These different mechanisms in terms of sex determination sexbased differences in lifespan longevity seem to be an adaptive response that enables an individual to adjust its sex for the greatest expected fitness (Charnov and Bull, 1977).

For adaptive organisms, variation in the sex-ratio is considerably easier (Korpelainen, 1990). A recent study outlined evidence for environmental sex determination (ESD) in E. marinus, with the photoperiod as the main influential factor in sex determination (Guler et al., 2012). Another sex-determining factor in E. marinus populations was correlated with feminizing parasite infections, which leads to a highly female-biased population (Ford et al., 2006; Short et al., 2012). This parasitic phenomenon results in the occurrence of intersex individuals. In dioecious species (such as E. marinus), both male and female sexual characteristics exist in the same individual; these individuals suffer from reduced fitness compared to normal individuals (Jobling et al., 2002; Kelly et al., 2004). An intersexed and female-biased population of E. marinus shows long-term viability, suggesting a selective advantage for female-biased populations owing to a decrease in the reproductive rate of intersex individuals (Martins et al., 2009; Ford et al., 2003).

Our study was based on the following evidence: i) the reproductive potential increases when a female dominance exists in the population (Emmerson, 1994) and ii) populations with the capability of adjusting their sex-ratios will experience a lessened impact under conditions of high disturbance (density-independent mortality) (Paoletti and Cantarino, 2002). Assuming that the E. marinus populations are able to adjust their sex-ratio in response to environmental variables, the aim of this study was to test whether fluctuations in the sex-ratio may be a mechanism of persistence and resilience in macroinvertebrate populations against natural disturbances such as climate change. To achieve this, the population response under climate change scenarios was forecasted using a dynamic model of E. marinus populations.

\section{Material and methods}

\subsection{Data and the population dynamics model}

In the Mondego estuary (western coast of Portugal, $40^{\circ} 08^{\prime} \mathrm{N} 8^{\circ} 50^{\prime} \mathrm{W}$ ), E. marinus is an abundant species in the intertidal communities and lives in association with the brown algae $F$. vesiculosus (Marques et al., 1993). At this location, it presents an important prey species for the upper trophic levels, specifically birds (Múrias et al., 1996, 1997). Data from previous studies on the productivity, growth, embryonic development and fecundity of E. marinus (Maranhão et al., 2001; 
Table 2

Mains symbols, description, units, initial values used in each scenario and estimation method of parameters.

\begin{tabular}{|c|c|c|c|c|c|c|c|c|c|}
\hline \multirow[t]{2}{*}{ Parameter (symbol) } & \multirow[t]{2}{*}{ Description } & \multirow[t]{2}{*}{ Units } & \multirow[t]{2}{*}{ Base model } & \multicolumn{2}{|c|}{ T scenario } & \multicolumn{2}{|c|}{ S scenario } & \multicolumn{2}{|l|}{ R scenario } \\
\hline & & & & $+2{ }^{\circ} \mathrm{C}$ & $+4{ }^{\circ} \mathrm{C}$ & $+5 \mathrm{psu}$ & $-5 \mathrm{psu}$ & Female biased & Male biased \\
\hline$J_{\text {Init }}$ & Initial density of juveniles & Individuals $\mathrm{m}^{-2}$ & \multicolumn{7}{|c|}{ 72/experimental } \\
\hline$W_{J_{\text {Init }}}$ & Initial Weight of juveniles & $\mathrm{mg}$ & \multicolumn{7}{|c|}{$0.065369 /$ experimental } \\
\hline Days $_{J}$ & Juveniles duration & Days & \multicolumn{7}{|c|}{ 60/experimental } \\
\hline mort $_{J}$ & Juveniles mortality & Per day & \multicolumn{7}{|c|}{$0.05 /$ experimental } \\
\hline growth $_{I F}$ & $\begin{array}{l}\text { Rate of transfer from juveniles } \\
\text { to immature females }\end{array}$ & Per day & \multicolumn{5}{|c|}{$0.0085 /$ calibration } & 0.0095 calibration & 0.0075 calibration \\
\hline growth $_{M}$ & $\begin{array}{l}\text { Rate of transfer from juveniles } \\
\text { to males }\end{array}$ & Per day & \multicolumn{5}{|c|}{$0.009 /$ calibration } & 0.008 calibration & 0.01 calibration \\
\hline$M_{\text {Init }}$ & Initial density of males & Individuals $\mathrm{m}^{-2}$ & \multicolumn{7}{|c|}{ 18/experimental } \\
\hline Days $_{M}$ & Males duration & Days & \multicolumn{7}{|c|}{ 500/experimental, calibration } \\
\hline Mort $_{M}$ & Males mortality & Per day & \multicolumn{7}{|c|}{ 0.024/experimental, calibration } \\
\hline$I F_{\text {Init }}$ & Initial density of & Individuals $\mathrm{m}^{-2}$ & \multicolumn{7}{|c|}{ 16/experimental } \\
\hline
\end{tabular}

Maranhão and Marques, 2003) were used to calibrate and validate a population dynamics model for this amphipod (Martins et al., 2002).

For modeling purposes, the population was divided into the following four groups: juveniles, immature (non-reproductive) females, adult (reproductive) females and males (Fig. 1). Growth, maturation (the rate of transfer from immature females to adult females), mortality and recruitment (the reproduction rate of adult females) regulate the variation in group density over time. In addition to measuring density, the model also calculates the variation in group weight over time according to a temperature-dependent modified von Bertalanffy model; this particular model has been considered suitable to describe E. marinus growth (see Marques, 1989; Marques and Nogueira, 1991). The number of newly hatched juveniles was made dependent on the size of the female, the temperature and the salinity (Table 1) in accordance with the experimental data (Maranhão and Marques, 2003). The initial model, designated hereafter as the base model, was run using the temperature and salinity data sets. The data were collected at the Mondego estuary in 1994-1995 (Fig. 2). Temperature and salinity are the forcing functions that regulate reproduction and growth (see Martins et al., 2002 for details).

\subsection{Scenario simulations}

Scenario simulations were run in two distinct phases, as follows: phase I included the variations in temperature and salinity according to the expected variations caused by global warming (IPCC, 2007), and phase II included the combined effects of temperature and salinity variations, with different realistic proportions of the sex-ratio.

According to the IPCC (Intergovernmental Panel on Climate Change) (2007), climate change predictions include variations in temperature with expected increases of approximately $2-4{ }^{\circ} \mathrm{C}$, a rise in sea level and extreme weather events such as droughts and heavy precipitation that may affect salinity due to changes in the riverine freshwater input (Cayan and Peterson, 1993; Justić et al., 1996).

Based on these predictions, our phase I study evaluated the effects of temperature increases of 2 and $4{ }^{\circ} \mathrm{C}$ and salinity fluctuations of $\pm 5 \mathrm{psu}$ on the variation in E. marinus populations; these evaluations correspond to scenarios $\mathrm{T}$ and $\mathrm{S}$, respectively. The simultaneous and combined effects of $\mathrm{T}$ and $\mathrm{S}$ variations on the E. marinus populations were also simulated through T-S scenarios.

In phase II, the scenarios that were simulated during phase I were combined with different sex-ratio values (scenario R) to assess whether fluctuations in the sex-ratio could alter the effects caused by variations in temperature and salinity (T-R, S-R and T-S-R scenarios). These values include a sex-ratio proportion of $1: 1,>1$ for a male-biased population and $<1$ for a female population.

Realistic sex-ratio fluctuations were achieved through controlled changes in the fluxes growth $h_{I F}$ and growth ${ }_{M}$. These fluctuations were achieved by increasing the initial values of growth ${ }_{I F}$ and growth ${ }_{M}$ used in the base model to obtain female- and male-biased sex-ratios, respectively. The sum of the two fluxes was the same as in the base model, which ensured that the model validation was not affected.

The initial values used in each simulation are shown in Table 2. Scenario simulations were run for 11 years.

\section{Results}

The simulated temperature increases (phase I, scenario T) caused a progressive decline in the density of the E. marinus populations. A more severe effect was observed when the temperature increased $4{ }^{\circ} \mathrm{C}$ (Fig. 3a). Simulated salinity changes (phase I, scenario S) had two opposite effects on the amphipod populations. While a decrease in salinity had a negative effect on the long-term variation in the population, a salinity increase seemed to favor the population by causing a gradual increase in density over time (Fig. 3b). When salinity and temperature increases were combined (phase I, scenario T-S), the positive effect of salinity was overshadowed by the population decline (Fig. 3c, d).

During the phase II simulations, all scenarios with male-biased populations presented with a gradual decline over time (Fig. 4). Scenarios with female-biased populations showed a greater resistance to temperature and/or salinity variations when compared to phase I populations (Fig. 4). Both phases show a decline in population when temperature increases were $4{ }^{\circ} \mathrm{C}$. A temperature increase of $2{ }^{\circ} \mathrm{C}$ conjugated with a salinity decrease of 5 psu (Fig. $4 \mathrm{~b}$, d) led to a decrease in density over time.

\section{Discussion}

Based on the modeling for predicted climate change scenarios, the E. marinus population shows two types of responses corresponding to the phase I or phase II simulations. Phase I simulations suggest that the E. marinus populations are negatively affected by the rise in temperature and the decrease in salinity. Based on models applied here, more severe effects were observed in higher temperature increases. While salinity increases alone would potentially increase the amphipod population, which is in accordance with experimental data (Vlasblom and Bolier, 1971; Pinkster and Broodbakker, 1980), the simultaneous increases in salinity and temperature appear to result in a gradual decrease in population density over time due to an apparent overlapping effect of temperature and salinity (Fig. 3).

Previous studies found that the reproductive biology of $E$. marinus is influenced by salinity and temperature (Marques and Nogueira, 1991; Maranhão et al., 2001; Maranhão and Marques, 2003). Vlasblom and Bolier (1971) stated that although E. marinus embryos can develop in salinities ranging between 4 and $7 \mathrm{psu}$, the number of emergent juveniles is reduced as a result. Pinkster and Broodbakker (1980) observed a reduction in brood size with decreasing salinity in laboratory experiments with Eulimnogammarus obtusatus. The following effects 

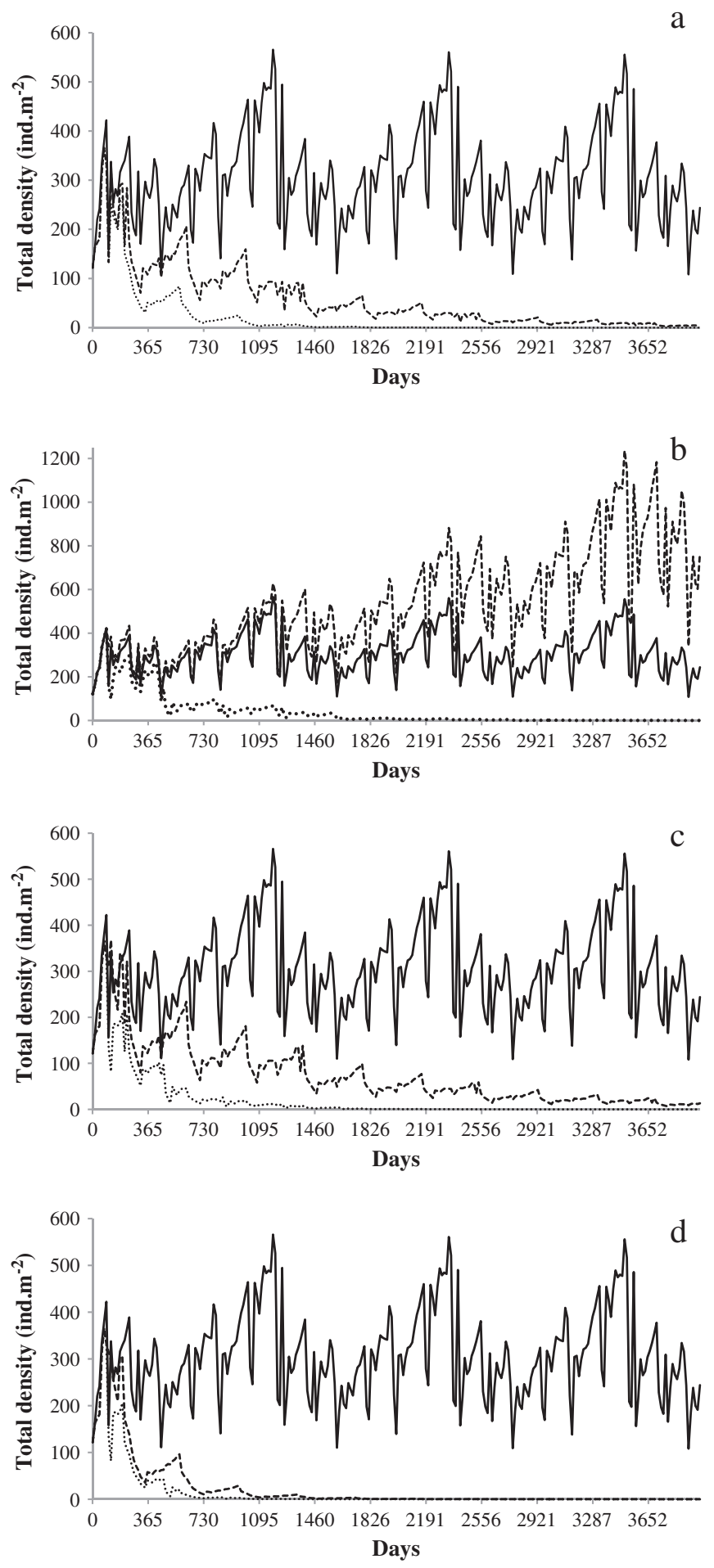

Fig. 3. Scenarios T, S, and T-S. The long-term variation in the Echinogammarus marinus total density (ind. $\mathrm{m}^{-2}$ ) under the base model conditions (solid line) and as follows: (a) - Temperature increases of $2{ }^{\circ} \mathrm{C}$ (dashed line) and $4{ }^{\circ} \mathrm{C}$ (dotted line), (b) - A salinity increase of 5 psu (dashed line) and a decrease of 5 psu (dotted line), (c) - A combined temperature increase of $2{ }^{\circ} \mathrm{C}$ and a salinity increase of $5 \mathrm{psu}$ (dashed line), and a combined temperature increase of $2{ }^{\circ} \mathrm{C}$ and a salinity decrease of 5 psu (dotted line) and (d) - A combined temperature increase of $4{ }^{\circ} \mathrm{C}$ and a salinity increase of 5 psu (dashed line) and a combined temperature increase of $4{ }^{\circ} \mathrm{C}$ and a salinity decrease of 5 psu (dotted line).

of temperature have been observed: embryonic development benefits from temperatures between 5 and $10^{\circ} \mathrm{C}$, reaching an optimum at $20{ }^{\circ} \mathrm{C}$; fecundity is higher at $10^{\circ} \mathrm{C}$ and lower at $20{ }^{\circ} \mathrm{C}$ (Vlasblom,
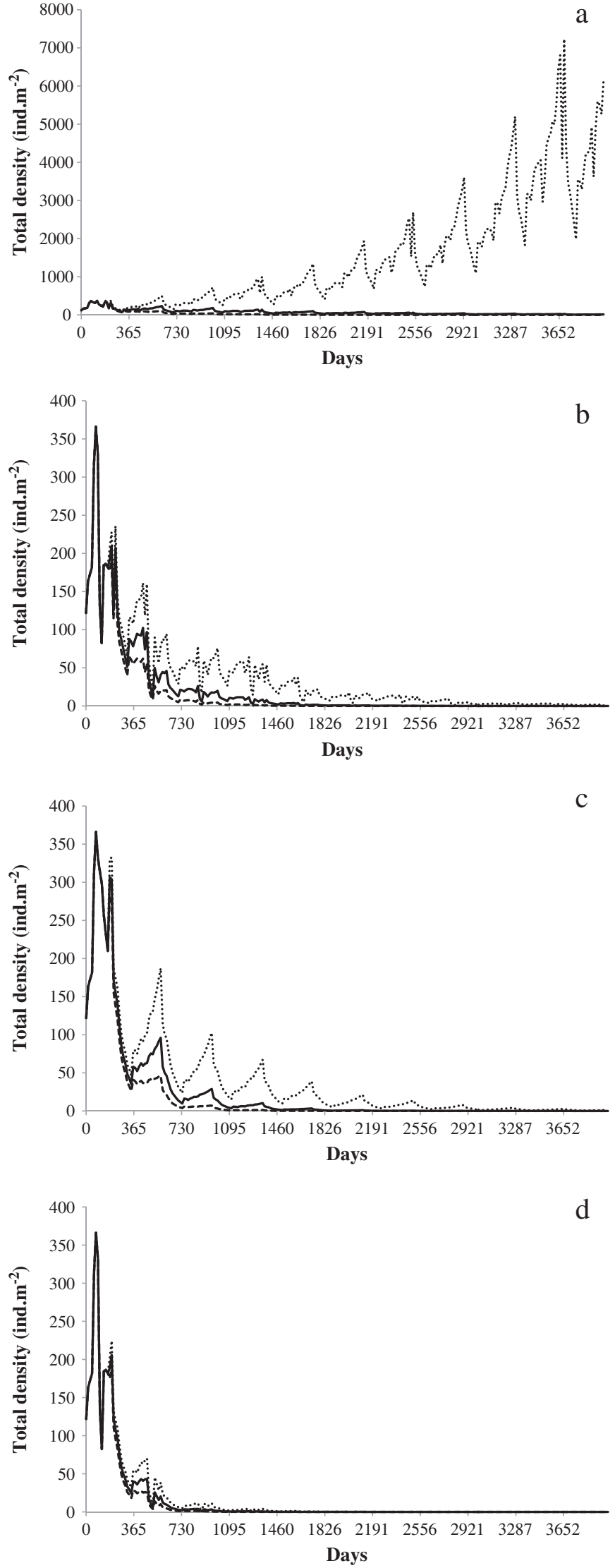
1969); and intrinsic growth rates were higher at $20^{\circ} \mathrm{C}$ and lower at $10{ }^{\circ} \mathrm{C}$ (Maranhão and Marques, 2003).

The decrease in density observed with increases in temperature may be due to metabolic constraints because the reproductive success of an organism is known to require the allocation of a certain amount of the assimilated energy to the gonads in competition with the interrelated processes of maintenance and somatic growth. Thus, higher water temperatures may result in increased metabolic maintenance costs that only allow for a decreased allocation of energy for reproduction (Cunha et al., 2000). Dorgelo (1973) reported an increase in the oxygen consumption rates of $E$. marinus with increased temperature. This finding suggests the occurrence of a greater energetic demand from the metabolic processes of maintenance and, as a consequence, the production of smaller broods might reduce the amount of energy expended in reproduction.

Results from phase II study suggest that male-biased populations of the amphipod E. marinus are less resistant and less resilient than female-biased populations to variations in temperature and salinity. Populations with a higher proportion of females can better cope with temperature increases of $2{ }^{\circ} \mathrm{C}$, either alone or in combination with salinity increases of $+5 \mathrm{psu}$. These populations exhibit a gradual increase in density over time, which is related to the enhanced recruitment rate of $E$. marinus at higher salinities. Even the female-biased populations of the Gammaridae seem unable of coping with temperature increases of $4{ }^{\circ} \mathrm{C}$; this issue is related to deviations from the optimum temperature range for growth and recruitment in E. marinus. Variations in E. marinus populations in scenarios with increasing temperature may be more dramatic if the overall increase in temperature throughout this century is greater than $4{ }^{\circ} \mathrm{C}$ (up to $6.4^{\circ} \mathrm{C}$ ). Such an increase has been predicted by the IPCC (2007) if growth in the global population and economy and the intensive consumption of fossil fuels persists.

Other issues are related to climate change in regards to increases in the extent and frequency of extreme events, such as floods and droughts (Jentsch and Beierkuhnlein, 2008). These extreme events, apart from causing fluctuations in salinity, have a negative effect on estuarine benthic invertebrates. In such scenarios, the general species diversity and the abundance of the dominant species decrease (e.g., Bradt et al., 1999; Argerich et al., 2004; Fritz and Dodds, 2004; Robinson et al., 2004; Cardoso et al., 2008). Studies on Corophium orientale reveled a decreased of more than $95 \%$ in the mean density of $C$. orientale after the drought period. A result of flow increases due to flooding, amphipods can be dragged out from the sediment (Gamito et al., 2010). In the present work, we took into account the complex configuration of the Mondego. Areas where the flow is less intense allow amphipods to take refuge against flooding, allowing a later recovery to previous levels and promoting high resilience. The sex-ratio is another sign of resilience against unfavorable conditions caused by climate change.

Female-biased populations of $E$. marinus seem to be more resistant to less favorable conditions such as global warming (Fig. 4) or intersexuality (Martins et al., 2009). Studies on the dispersion of amphipods and their successful establishment under new conditions also show that a population structure characterized by more females than over males during the reproductive period allows for more rapid population growth. This phenomenon is a common adaptation by many amphipod species and has been described for Gmelinoides fasciatus populations in the Angara River reservoirs (Vershinin, 1967) as well as Lake Onega (Berezina and Panov, 2003) and Neva Bay (Berezina, 2005). Other species, such as some nematodes, exhibit male-biased populations when conditions are adverse (Snyder et al., 2006).

The causes of sex determination in amphipods are believed to be multi-factorial (Guler et al., 2012). For the amphipod Corophium volutator, biased sex-ratios may be due to the differential predation on adult males by the migrant shorebird. Other sex-ratio deviations in the gammaridean amphipod Hyalella sp. appear to be related to a reproductive strategy (Castiglioni and Buckup, 2008) in which males spend more time choosing, holding and carrying the females; thus, the males are more susceptible to predators than females (Moore, 1981; Powell and Moore, 1991; Kevrekidis, 2005).

Sex determination in $E$. marinus has been reported to be linked with feminizing parasites (Ford et al., 2006). A recent study suggests that there is evidence for environmental sex determination (ESD) in E. marinus under laboratory conditions, where the photoperiod was shown to be an influential factor in sex determination (Guler et al., 2012). Other studies on the amphipod Gammarus duebeni indicate that temperature and an interaction between temperature and photoperiod act as cues for ESD as well as the variation in degrees of ESD between different populations (animals from northern climates show ESD, while animals from southern climates do not) (Naylor et al., 1988). These studies demonstrate that amphipods have an exceptional flexibility in sex determination, in which individuals make facultative adjustments to the sex-ratios of their offspring in response to local conditions (Charnov, 1982; Hardy, 2002; West et al., 2000). Moreover, it has been established that fluctuating environments can favor the evolution of mixed strategies (Haccou and Iwasa, 1995; McNamara, 1995; Sasaki and Ellner, 1995). Although it is not fully understood why different organisms show so much variation in the amount and precision with which they adjust the sex-ratio of their offspring, this phenomenon highlights the fact that sex-ratio adjustment in populations seems to be a mechanism by which those populations maintain their fitness.

Much of the literature on the biogeographic response to climate has tended to focus on long-term trends, such as the poleward progression of species boundaries and changes in phenology (e.g., Parmesan, 2006; Helmuth et al., 2006; Hawkins et al., 2009; Giménez, 2011).

The E. marinus populations reported in this study are located at the southernmost limit of their species distribution, the Mondego estuary (on the western coast of Portugal) (Maren, 1975a, 1975b; Marques and Bellan-Santini, 1993), where the recent average annual water temperature varied between 10 and $27{ }^{\circ} \mathrm{C}$ (unpublished data from July 2011 to August 2012). Several global warming models and scenarios predict that warming in Western Europe will range between 1.1 and $3.5^{\circ} \mathrm{C}$ by the end of the 21st century (Meehl et al., 2005). These warming scenarios place E. marinus populations from the Mondego estuary at considerable risk, particularly if the temperature variance is $\geq 2{ }^{\circ} \mathrm{C}$. This result is accordance with our results. In these circumstances, the southernmost limit of the Gammaridae may become restricted to northern latitudes $\left(45-51^{\circ} \mathrm{N}\right)$, which currently have lower water temperatures that the Mondego estuary (Noppe et al., in press; Glé et al., 2008). According to global warming models (Meehl et al., 2005), the water temperature at these latitudes will rise to values similar to those currently found at the study site (the Mondego estuary). This result is in accordance with other studies where the northward movement of marine species driven by global warming has been predicted along European coast lines (Philippart et al., 2011). This phenomenon of migration will influence the food web at the ecosystem level (Cury et al., 2008).

In the Mondego estuary, the production of E. marinus and the annual average biomass is considered to be relatively high when compared to

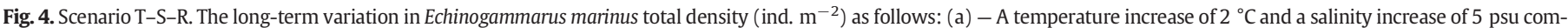

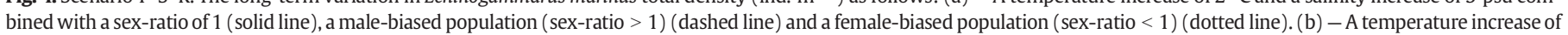

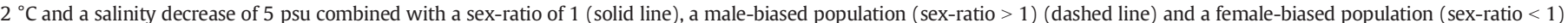

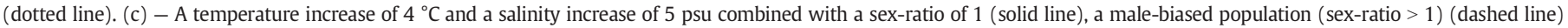

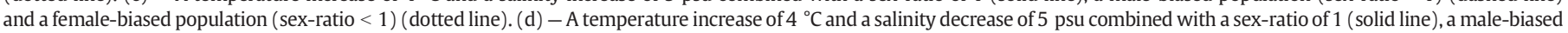
population ( sex-ratio $>1$ ) (dashed line) and a female-biased population (sex-ratio $<1$ ) (dotted line). 
values obtained for other amphipod species from temperate zones (Hastings, 1981; Carrasco and Arcos, 1984; Dauvin, 1988) and their ample intertidal distribution. This high biomass allows for accessibility to aquatic predators and birds, suggesting that this amphipod may play an important role in trophic dynamics. Thus, the biogeographical shift or population decline in E. marinus populations due to climate change will lead to important changes in the distribution of their predators/preys. Such a phenomenon may also lead to serious changes in the local or even national distribution of birds (the main predators). This scenario may impact the Mondego estuary ecosystem as a whole.

E. marinus populations will be adversely affected by increases in temperature of $\geq 2{ }^{\circ} \mathrm{C}$; as a result of these changes, the southernmost limit of E. marinus may be displaced approximately $5^{\circ} \mathrm{N}$. Populations able to adjust their sex-ratios may be more resilient to climatic changes. In the case of E. marinus, female-biased populations seem to be more resistant to rises in temperature than male-biased populations. When males become too rare to fertilize the available females, the population will collapse (Hatcher et al., 1999). Female-biased populations of $E$. marinus may only subsist up to certain thresholds of temperature and sexual bias, in which the number of males are sufficient to fertilize the available females.

\section{Acknowledgments}

The authors are indebted to all of their colleagues at IMAR - The Institute of Marine Research, Marine and Environmental Research Centre, who assisted in field and laboratory work.

The present study was carried using financial support from R\&D research projects 3M-RECITAL (LTER/BIA-BEC/0019/2009), INPACTAR (PTDC/MAR/111537/2009), and CIÊNCIA 2007 (FCT, QREN, COMPETE). This study was also subsidized by the European Social Fund and the MCTES national funds, and through the POPH (Human Potential Operational Programme) - NSRF (National Strategic Reference Framework4.4.)

\section{References}

Appadoo C, Myers AA. Reproductive bionomics and life history traits of three gammaridean amphipods, Cymadusa filosa Savigny, Ampithoe laxipodus Appadoo and Myers and Mallacoota schellenbergi Ledoyer from tropical Indian Ocean (Mauritius). Acta Oecol 2004;26:227-38.

Argerich A, Puig MA, Pupilli E. Effect of floods of different magnitude on the macroinvertebrate communities of Matarranya stream (Ebro River basin, NE Spain). Limnetica 2004:423:283-94.

Beaugrand G, Reid PC, Ibanez F, Lindley JA, Edwards M. Reorganization of North Atlantic marine copepod biodiversity and climate. Science 2002;296:1692-4.

Berezina NA. Seasonal dynamics and fecundity of Gmelinoides fasciatus (Stebbing 1899) (Amphipoda: Crustacea) in macrophyte zone of northern Neva Bay (Gulf of Finland, Baltic Sea). Zool Zh 2005;4:411-9.

Berezina NA, Gubelit YI. Changes in coastal ecosystem of the eastern Baltic Sea under eutrophication and climate variability. IEEE/OES Baltic International Symposium (BALTIC) (May 2012); 2012. p. 1-4.

Berezina NA, Panov VE. Establishment of the Baikalian amphipod Gmelinoides fasciatus (Amphipoda, Crustacea) in Lake Onega. Entomol Rev 2003:83:171-4.

Bradt P, Urban M, Goodman N, Bissell S, Spiegel I. Stability and resilience in benthic macroinvertebrate assemblages. Impact of physical disturbance over twenty-five years. Hydrobiologia 1999;403:123-33.

Cardoso RS, Veloso VG. Population biology and secondary production of the sandhopper Pseudorchestoidea brasiliensis (Amphipoda: Talitridae) at Prainha Beach, Brazil. Mar Ecol Prog Ser 1996;142:111-9.

Cardoso P, Raffaelli D, Lillebø AI, Verdelhos T, Pardal MA. The impact of extreme flooding events and anthropogenic stressors on the macrobenthic communities' dynamics. Estuar Coast Shelf Sci 2008;76:553-65.

Carrasco FD, Arcos DF. Life history and production of a cold-temperate population of the sublittoral amphipod Ampelisca aroucana. Mar Ecol Prog Ser 1984;14:245-52.

Castiglioni DS, Buckup GB. Ecological traits of two sympatric species of Hyalella Smith, 1874 (Crustacea, Amphipoda, Dogielinotidae) from southern Brazil. Acta Oecol 2008;33:36-48.

Cayan DR, Peterson DH. Spring climate and salinity in the San Francisco Bay estuary. Water Resour Res 1993;29:293-303.

Charnov EL. The theory of sex allocation. Princeton: Princeton University Press; 1982.

Charnov EL, Bull JJ. When is sex environmentally determined? Nature 1977;266:828-30.

Cunha MR, Moreira MH, Sorbe JC. Predicting amphipods' brood size variation in brackish environments: an empirical model for Corophium multisetosum Stock,
1952 (Corophiidae) in Ria de Aveiro (NW Portugal). J Exp Mar Biol Ecol 2000;248:207-23.

Cury PM, Shin Y, Planque B, Durant JM, Fromentin JM, Kramer-Schadt S, et al. Ecosystem oceanography for global change in fisheries. Trends Ecol Evol 2008;23:338-46.

Dauvin JC. Life cycle, dynamics and productivity of Crustacea Amphipoda from western English Channel. 4. Ampelisca armoricana Bellan-Santini et Dauvin. J Exp Mar Biol Ecol 1988:123:235-52.

Denny MW, Wethey DS. Physical processes that generate patterns in marine communities In: Bertness MD, Gaines SD, Hay ME, editors. Marine community ecology. Sunderland, MA: Sinauer; 2001. p. 3-37.

Donn Jr TE, Croker RA. Life-history patterns of Haustorius canadensis (Crustacea, Amphipoda) in northern New England. Can J Zool 1986;64:99-104.

Dorgelo J. Comparative ecophysiology of Gammarids (Crustacea: Amphipoda) from marine, brackish, and fresh-water habitats exposed to the influence of salinitytemperature combinations. III: Oxygen uptake. Neth J Sea Res 1973;7:253-66.

Emmerson WD. Seasonal breeding cycles and sex-ratios of eight species of crabs from Mgazana, a mangrove estuary in Transkei, southern Africa. J Crustacean Biol 1994; 14(3):568-78

Ford AT, Fernandes TF, Rider SA, Read PA, Robinson CD, Davies IM. Reproduction in the amphipod, Echinogammarus marinus: a comparison between normal and intersex specimens. J Mar Biol Assoc UK 2003:83:937-40.

Ford AT, Rodgers-Gray TP, Davies IM, Dunn AM, Read PA, Robinson CD, et al. Abnorma gonadal morphology in intersex, Echinogammarus marinus (Amphipoda): a possible cause of reduced fecundity? Mar Biol 2005;147:913-8.

Ford AT, Fernandes TF, Robinson CD, Davies IM, Read PA. Can industrial pollution cause intersexuality in the amphipod, Echinogammarus marinus? Mar Pollut Bull 2006;53: 100-6.

Fritz KM, Dodds WK. Resistance and resilience of macroinvertebrate assemblages to drying and flood in a tallgrass prairie stream system. Hydrobiologia 2004;527: 99-112.

Fujii T. Climate change, sea level rise and implications for coastal and estuarine shoreline management with particular reference to the ecology of intertidal benthic macrofauna in NW Europe. Biology 2012;1:597-616. [Review].

Gamito S, Chainho P, Costa JL, Medeiros LP, Costa MJ, Marques JC. Modelling the effects of extreme events on the dynamics of the amphipod Corophium orientale. Ecol Model 2010;221:459-66

Giménez L. Exploring mechanisms linking temperature increase and larval phenology: the importance of variance effects. J Exp Mar Biol Ecol 2011;400:227-35.

Glé C, Del Amo Y, Sautour B, Laborde P, Chardy P. Variability of nutrients and phytoplankton primary production in a shallow macrotidal coastal ecosystem (Arcachon Bay France). Estuar Coast Shelf Sci 2008;76:642-56.

Guler Y, Short S, Kile P, Ford A. Integrating field and laboratory evidence for environmental sex determination in the amphipod, Echinogammarus marinus. Mar Biol 2012;159: 2885-90.

Haccou P, Iwasa Y. Optimal mixed strategies in stochastic environments. Theor Popul Biol 1995; $47: 212-43$

Hardy ICW. Sex-ratios: concepts and research methods. Cambridge: Cambridge University Press; 2002.

Harley CDG, Hughes AR, Hultgren KM, Miner BG, Sorte CJB, Thornber CS, et al. The impacts of climate change in coastal marine systems. Ecology 2006;9:228-41.

Hastings MH. The life cycle and productivity of an intertidal population of the amphipod Ampelisca brevicornis. Estuar Coast Shelf Sci 1981;12:665-77.

Hatcher MJ, Taneyhill DE, Dunn AM. Population dynamics under parasitic sex-ratio distortion. Theor Popul Biol 1999;56:11-28.

Hawkins SJ, Sugden HE, Mieszkowska N, Moore P, Poloczanska E, Leaper R, et al. Consequences of climate driven biodiversity changes for ecosystem functioning of North European rocky shores. Mar Ecol Prog Ser 2009;396:245-59.

Helmuth B, Mieszkowska N, Moore P, Hawkins SJ. Living on the edge of two changing worlds: forecasting the responses of rocky intertidal ecosystems to climate change. Annu Rev Ecol Evol Syst 2006;37:373-404.

Herbert RJH, Hawkins SJ, Sheader M, Southward AJ. Range extension and reproduction of the barnacle Balanus perforatus in the eastern English Channel. J Mar Biol Assoc UK 2003;83:73-82.

IPCC (Intergovernmental Panel on Climate Change). Climate change 2007: the physical science basis. Summary for policymakers. Contribution of Working Group I to the Fourth Assessment Report of the Intergovernmental Panel on Climate Change. Geneva, Switzerland; 200718.

Jentsch A, Beierkuhnlein C. Research frontiers in climate change: effects of extreme meteorological events on ecosystems. C R Geosci 2008;340:621-8.

Jobling S, Coey S, Whitmore JC, Kime DE, Van Look KJN, McAllister BG, et al. Wild intersex roach (Rutilus rutilus) have reduced fertility. Biol Reprod 2002;67:515-24.

Justić D, Rabalais NN, Turner RE. Effects of climate change on hypoxia in coastal waters: a doubled $\mathrm{CO}_{2}$ scenario for the northern Gulf of Mexico. Limnol Oceanogr 1996;41: 992-1003.

Kelly A, Hatcher MJ, Dunn AM. Intersexuality in the amphipod Gammarus duebeni results from incomplete feminisation by the vertically transmitted parasitic sex-ratio distorte Nosema granulosis. Evol Ecol 2004;18:121-32.

Kevrekidis T. Life history, aspects of reproductive biology and production of Corophium orientale (Crustacea: Amphipoda) in Monolimni lagoon (Evros Delta, north Aegean Sea). Hydrobiologia 2005;537:53-70.

Kolding S, Fenchel TM. Patterns of reproduction in different populations of five species of the amphipod genus Gammarus. Oikos 1981;37:167-72.

Korpelainen $\mathrm{H}$. Sex-ratios and conditions required for environmental sex determination in animals. Biol Rev 1990;65:147-84.

Lawrence AJ, Soame JM. The effects of climate change on the reproduction of coastal invertebrates. Ibis 2004;146:29-39. (Suppl.). 
Lucey SM, Nye JA. Shifting species assemblages in the Northeast US Continental Shelf Large Marine Ecosystem. Mar Ecol Prog Ser 2010;415:23-33.

Maranhão P, Marques JC. The influence of temperature and salinity on the duration of embryonic development, fecundity and growth of the amphipod Echinogammarus marinus Leach (Gammaridae). Acta Oecol 2003;24:5-13.

Maranhão P, Bengala N, Pardal M, Marques JC. The influence of environmental factors on the population dynamics, reproductive biology and productivity of Echinogammarus marinus Leach (Amphipoda, Gammaridae) in the Mondego estuary (Portugal). Acta Oecol 2001;22:139-52.

Maren MJ. Some notes on the intertidal gammarids (Crustacea, Amphipoda) from the Atlantic coast of the Iberian Peninsula. Beaufortia 1975a;23:153-68.

Maren MJ. The biology of Chaetogammarus marinus (Leach) and Eulimnogammarus obtusatus (Dahl), with some notes on other intertidal gammarid species (Crustacea, Amphipoda). Bijdr Dierkd 1975b;45:204-24.

Marques JC. Amphipoda (Crustacea) bentónicos da costa Portuguesa: Estudo taxonómico, ecológico e biogeográfico. [Unpublished PhD thesis]Coimbra: Universidade de Coimbra; 1989394.

Marques JC, Bellan-Santini D. Biodiversity in the ecosystem of the Portuguese continenta shelf: distributional ecology and the role of benthic amphipods. Mar Biol 1993;115: 555-64.

Marques JC, Nogueira A. Life cycle, population dynamics and production of Echinogammarus marinus (Leach) (Amphipoda) in the Mondego estuary (Portugal) Acta Oceanol 1991;11:213-23.

Marques JC, Rodrigues LB, Nogueira A. Intertidal macrobenthic communities structure in the Mondego estuary (Western Portugal): reference situation. Vie Milieu 1993;43: 177-87.

Martins I, Maranhão P, Marques JC. Modelling the effects of salinity variation on Echinogammarus marinus Leach (Amphipoda, Gammaridae) density and biomass in the Mondego estuary (Western Portugal). Ecol Model 2002;152:247-60.

Martins I, Ford AT, Fernandes TF. Intersexuality incidence, sex-ratio fluctuations and intersex reproductive output as factors affecting the temporal variation of intersexed populations of the marine amphipod Echinogammarus marinus. Mar Environ Res 2009;68:163-9.

McKenney Jr CL. The combined effects of salinity and temperature on various aspects of the reproductive biology of the estuarine mysid, Mysidopsis bahia. Invert Reprod Dev 1996;29(1):9-18.

McNamara J. Implicit frequency dependence and kin selection in fluctuating environments. Evol Ecol 1995;9:185-203.

Meehl AG, Washington WM, Collins WD, Arblaster JM, Hu A, Buja LE, et al. How much more global warming and sea level rise? Science 2005;307:1769-72.

Mieszkowska N, Hawkins SJ, Burrows MT, Kendall MA. Long-term changes in the geographic distribution and population structures of Osilinus lineatus (Gastropoda: Trochidae) in Britain and Ireland. J Mar Biol Assoc UK 2007;87:537-45.

Moore PG. The life histories of the amphipods Lembos wehsteri (Bate) and Corophium bonnellii (Milne Edwards) in kelp holdfasts. J Exp Mar Biol Ecol 1981;49:1-50.

Mueter FJ, Litzow MA. Sea ice retreat alters the biogeography of the Bering Sea continental shelf. Ecol Appl 2008;18:309-20.

Múrias T, Cabral JA, Marques JC, Goss-Custard JD. Short-term effects of intertida macroalgal blooms on the macrohabitat selection and feeding behaviour of wading birds in the Mondego estuary (west Portugal). Estuar Coast Shelf Sci 1996;43:677-88.

Múrias T, Cabral JA, Lopes R, Marques JC. Low-water use of the Mondego estuary (West Portugal) by waders (Charadrii). Ardeola 1997;44:79-91.

Naylor C, Adams J, Greenwood PJ. Variation in sex determination in natural populations of a shrimp. J Evol Biol 1988;1:355-68.

Noppe H, Verslycke T, De Wulf E, Verheyden K, Monteyne E, Van Caeter P, et al. Occurrence of estrogens in the Scheldt Estuary: a 2-year survey. Ecotoxicol Environ Saf 2007;66:1-8.
Paoletti MG Cantarino CM. Sex-ratio alterations in terrestrial woodlice populations (Isopoda: Oniscidea) from agroecosystems subjected to different agricultural practices in Italy. Appl Soil Ecol 2002;19:113-20.

Pardal MA, Marques JC, Metelo I, Lillebø AI, Flindt MR. Impact of eutrophication on the life cycle, population dynamics and production of Ampithoe valida (Amphipoda) along an estuarine spatial gradient (Mondego estuary, Portugal). Mar Ecol Prog Ser 2000;162: 207-19.

Parmesan C. Ecological and evolutionary responses to recent climate change. Annu Rev Ecol Evol Syst 2006;37:637-69.

Philippart CJM, Anadón R, Danovaro R, Dippner JW, Drinkwater KF, Hawkins SJ, et al. Impacts of climate change on European marine ecosystems: observations, expectations and indicators. J Exp Mar Biol Ecol 2011:400:52-69.

Pianka ER. On r and K selection. Am Nat 1970;104:592-7.

Pinkster S, Broodbakker NW. The influence of environmental factors on distribution and reproductive success of Eulimnogammarus obtusatus (Dahl, 1938) and other estuarine gammarids. Crustaceana 1980;6:225-41. [Suppl.].

Powell R, Moore PG. The breeding cycles of females of seven species of amphipod (Crustacea) from the Clyde Sea area. J Nat Hist 1991;25:435-79.

Robinson CT, Uehlinger U, Monaghan MT. Stream ecosystem response to multiple experimental floods from a reservoir. River Res Appl 2004;20:359-77.

Sagarin RD, Barry JP, Gilman SE, Baxter CH. Climate related changes in an intertidal community over short and long time scales. Ecol Monogr 1999;69:465-90.

Sainte-Marie B. A review of the reproductive bionomics of aquatic gammaridean amphipods: variation of life history traits with latitude, depth, salinity and superfamily. Hydrobiologia 1991;223:189-227.

Sasaki A, Ellner S. The evolutionarily stable phenotype distribution in a random environment. Evolution 1995;49:337-50.

Short S, Guler Y, Kille P, Ford AT. Paramyxean-microsporidian co-infection in amphipods: is the consensus that Microsporidia can feminise their hosts presumptive? Int J Parasitol 2012;42:683-91.

Skadsheim A. Coexistence and reproductive adaptations of amphipods: the role of environmental heterogeneity. Oikos 1984;43:94-103.

Snyder DW, Opperman CH, Bird DM. A method for generating Meloidogyne incognita males. J Nematol 2006;38:192-4.

Somero G. The physiology of global change: linking patterns to mechanisms. Ann Rev Mar Sci 2012;4:39-61.

Southward AJ, Hawkins SJ, Burrows MT. Seventy years' observations of changes in distribution and abundance of zooplankton and intertidal organisms in the western English Channel in relation to rising sea temperature. J Therm Biol 1995;20(1-2): 127-55.

Trivers RL, Willard DE. Natural selection of parental ability to vary the sex-ratio of offspring. Science 1973;179:90-2.

Van Dolah RF, Bird E. A comparison of reproductive patterns in epifaunal and infaunal gammaridean Amphipoda. Estuar Coast Shelf Sci 1980;11:593-604.

Vershinin NV. Biology and distribution of Gmelinoides fasciatus Stebb. in Bratsky Reservoir. Zool Zh 1967;46(7):1024-30.

Vlasblom AG. A study of a population of Marinogammarus marinus (Leach) in the Oosterschelde. Neth J Sea Res 1969;4:317-38.

Vlasblom AG, Bolier G. Tolerance of the embryos of Marinogammarus marinus and Orchestia gammarella to lowered salinity. 1971;5:334-41.

West SA, Herre EA, Sheldon BC. The benefits of allocating sex. Science 2000;290:288-90.

Wethey DS, Woodin SA. Ecological hindcasting of biogeographic responses to climate change in the European intertidal zone. Hydrobiologia 2008;606:139-51.

Wildish DJ. Secondary production of four subtidal, soft-sediment amphipod populations in the Bay of Fundy. Can J Zool 1984;7:1027-33.

Wildish DJ. Biased sex-ratios in invertebrates. In: Adiyodi, editor. Advances in invertebrate reproduction. India: Peralam-Kenoth; 1997. p. 3-23. 